\title{
KOMPARASI PATIKRAMA TATANEN HUMA SUNDA DI paDUKUHAN daN peDEsaAN dI JaWa Barat
}

\section{A STUDY COMPARATIVE OF SUNDANESE PATIKRAMA TATANEN HUMA $A T$ PADUKUHAN AND RURAL AREA IN WEST JAVA}

\author{
Edi Setiadi Putra, Mohammad Djalu Djatmiko, Mohamad Arif Waskito \\ Program Studi Desain Produk, Fakultas Seni Rupa dan Desain, \\ Institut Teknologi Nasional Bandung \\ Jl. PKH. Hasan Mustapa No.23, Bandung, Jawa Barat, Indonesia \\ e-mail: edsetia@itenas.ac.id,djaluds@itenas.ac.id, mawaskito@itenas.ac.id
}

\begin{abstract}
Abstrak
Penelitian ini bertujuan untuk mengungkap makna Patikrama Tatanen Huma Sunda, suatu prinsip pengelolaan ladang yang terkait dengan sistem pelestarian ekosistem hutan tropis. Patikrama Tatanen Huma tersirat dalam beberapa naskah kuno, yang tata caranya dilestarikan oleh beberapa padukuhan kabuyutan Sunda. Banyak penelitian tentang patikrama tatanen huma ini terfokus pada kehidupan pahuma di Desa Kanekes dan kawasan kasepuhan lain, namun belum banyak yang melakukan studi komparasi dengan kegiatan huma di kawasan padesaan. Melalui pendekatan etnografi, penelitian dilakukan pada beberapa kawasan padesaan di Jawa Barat yang masih melakukan aktivitas pertanian huma yang produktif. Penelitian ini diharapkan dapat mengetahui adanya perbedaan dan persamaan paradigma dalam aplikasi Patikrama Tatanen Huma Sunda. Komparasi ini dapat memberikan wawasan tentang konsekuensi perubahan serta nilai manfaat dalam pelestariannya, sehingga menjadi bahan pertimbangan dalam pemulihan ekosistem desa hutan dan menghidupkan kembali prinsip bertani yang sesuai dengan akar budaya masyarakat petani di kawasan padesaan.
\end{abstract}

Kata kunci: patikrama tatanen, huma, Sunda, etnografi.

\begin{abstract}
This study aims to reveal the meaning of Sundanese Patikrama Tatanen Huma, a principle of field management related to the system of preserving tropical forest ecosystems. Patikrama Tatanen Huma is implied in some ancient manuscripts, the procedure of which is preserved by some Sundanese kabuyutan. Many of the researches on the patriarchal order of public relations focused on the life of pahuma in the village of Kanekes and other areas of Kasepuhan, but not many have conducted comparative studies with the activities of public relations in the region. Through an ethnographic approach, research was conducted in several rural areas in West Java that were still carrying out productive agricultural activities. This research was intended to find out the differences and similarities in the paradigm in the application of Huma Sunda Patikrama Tatanen. This comparison can provide insight into the consequences of change and the value of benefits in its preservation, so that it becomes a consideration in restoring forest village ecosystems and reviving farming principles that are in accordance with the cultural roots of farmers in the rural areas.
\end{abstract}

Keywords: Patikrama Tatanen, Huma, Sunda, Ethnography 


\section{A. PENDAHULUAN}

Beberapa desa hutan di Jawa Barat pada masa kini melakukan kegiatan pertanian di kawasan hutan. Padi dan palawija dibudidayakan di antara pepohonan kayu. Sistem pertanian ini sering disebut tumpang sari, yaitu memanfaatkan lahan tanah di bawah pohon besar. Sistem pertanian ini merupakan solusi terbaik dalam bisnis agroforestri sekaligus melestarikan ekosistem hutan. Yang menarik perhatian adalah para petani desa hutan juga menanam padi di bawah pepohonan yang disebut huma desa. Petani menanam varietas padi unggul untuk lahan huma atau padi gogo, yaitu jenis inpago yang tumbuh di lahan kering, dan memiliki daya tahan yang baik terhadap serangan wereng coklat dan hawar daun.

Prinsip huma dalam agroforestri bukan merupakan hal yang baru, karena di masyarakat Baduy,masih terpelihara sistem budidaya anekaragam campuran tanaman semusim dan tahunan di kawasan hutan. Sistem huma tersebut dikatagorikan sebagai agroforestri tradisional. Sistem huma dan reuma, merupakan sistem agroforestri.(Iskandar \& Iskandar, 2015)

Agroforestri di kawasan desa hutan sangat penting untuk dikembangkan, karena terbentuk kerjasama mutualistik antara petani dengan pengelola hutan. Petani di kawasan hutan kerap dicurigai sebagai perambah hutan, penyebab kebakaran hutan, penyebab penggundulan hutan dan berbagai hal lain yang merugikan bisnis kehutanan. Padahal sesungguhnya para petani di kawasan hutan justru merupakan masyarakat terdepan yang aktif melawan para perusak hutan.

Sistem agroforestri huma di padesaan tampaknya memiliki hubungan erat dengan sistem huma masyarakat Baduy. Apakah memiliki kesamaan atau perbedaan? untuk mengetahuinya, diperlukan penelitian khusus untuk memahami akar budaya huma.

Akar budaya pertanian masyarakat Sunda, adalah sistem pertanian huma dengan prinsip aturan kerja yang disebut dengan patikrama tatanen huma. Patikrama tatanen huma Sunda adalah peraturan adat tentang bagaimana tata-cara urang Sunda mengelola sistem pertanian huma di dataran tinggi dan kawasan hutan.

Patikrama Tatanen Huma Sunda merupakan prinsip ngahuma yang berlandaskan falsafah hidup masyarakat Sunda buhun yang disebut Pitarapuja Jati Sunda atau Sunda Wiwitan.Falsafah Sunda Wiwitan merupakan kepercayaan monotheis, karena terdapat prinsip adanya Batara Tunggal atau Sanghyang Tunggal (Yang Maha Esa), yang disebut juga Nungersakeun atau Sanghyang Keresa (Yang Maha Kuasa). Semua hal kehidupan berada dalam tangan Dzat Yang Maha Esa, yaitu Sanghyang Batara Tunggal. Setiap manusia yang menemui ajalnya, ruhnya akan kembali kepada Sang Maha Pencipta, yaitu Sanghyang Batara Tunggal. (Senoaji, 2012)

Akar budaya huma yang berlandaskan Pitarapuja Jati Sunda (Sunda Wiwitan), membentuk sistem pertanian sakral yang disebut Patikrama Tatanen Huma Sunda, yang hidup lestari di padukuhan atau perkampungan adat Sunda buhun (disebut juga kabuyutan atau perkampungan para sesepuh Sunda).

Salah satu komunitas kabuyutan yang menjadi referensi adalah masyarakat Baduy, yang bermukim di Desa Kaněkěs Kecamatan Leuwidamar Kabupaten Lebak. Kaněkěs merupakan desa yang sebagian besar dihuni oleh warga Baduy. Masyarakat Baduy Dalam yang biasa disebut Urang Tangtu, mendiami wilayahwilayah Kampung Cikeusik yang disebut Tangtu Pada Ageng; Warga Baduy yang mendiami Kampung Cibeo yang disebut Tangtu Parahiang; dan Warga Baduy yang mendiami Kampung Cikertawana yang disebut Tangtu Kadu Kujang.(Satriadi, 2015)

Dalam mempelajari adat leluhur, diperlukan cara pandang yang berbeda dalam memahami cara hidup masyarakat padukuhan, yang cenderung religius dan 
taat dalam ritual sakral, memiliki disiplin mutlak dalam adat, hormat pada patikrama karuhun. Untuk mengetahui prinsip leluhur, diperlukan refleksi ke masa lalu. Dalam budaya Sunda, dikenal istilah purwadaksi untuk memahami jati diri. Masyarakat Sunda masa kini, terlarang untuk melupakan akar budayanya. Seperti ujaran berikut: "Tunggul entong dirurud, catang entong dirumpak, hirup katungkulan ku umur, paeh henteu nyaho dimangsa. Sing emut kanapurwadaksi, purwa wiwitan, daksi wekasan. Hartina sing apal ka diri sorangan, asal timana? Cicingna dimana? Balikna kamana?(tonggak jangan dicabut, batang jangan dibelah, hidup dibatasi umur, mati tidak disangka, ingatlah kepada purwadaksi, purwa awal, daksi akhir, artinya harus pahami diri sendiri, asalnya dari mana? tinggalnya dimana? kembali kemana?). Dalam perubahan apapun yang terjadi, manusia Sunda memiliki prinsip untuk tidak pernah melupakan sejarah, asal muasal, jati diri dan keberadaan leluhurnya. Prinsip "tara lali $k a$ purwadaksi" yaitu "tara poho kana tali parantiyang berarti tidak melupakan kebiasaan yang diwariskan leluhur.

Purwadaksina secara etimologis, berasal dari kata purwa (sskr.) yang berarti: awal, permulaan, depan, yang terdahulu; timur (wetan), sedangkan daksina (sskr.) berarti kanan; selatan (kidul). (Zoetmulder, 2006). Pemaknaan puwa-daksi sebagai arah timur-selatan, berasal dari proses pendahuluan kehidupan dimana matahari terbit dari timur. Arah timur adalah penting dan sakral, karena itu dalam patikrama tatanen huma Sunda, huma terhormat terletak di sebelah timur. Pada Masyarakat Kanekes, huma untuk upacara adalah huma serang, yang terletak paling timur diantara huma-huma lainnya. Huma serang adalah huma terdepan yang paling dahulu mendapat sinar matahari. Arah selatan (kidul) juga merupakan arah sakral tempat pemukiman mandala atau wilayah kasepuhan.
Pada Masyarakat Kanekes, semua wanita yang bertugas menumbuk padi huma diharuskan menghadap ke arah selatan. Pemaknaan purwadaksi tersebut mencakup perlunya langkah sistematis untuk memahami pemikiran leluhur Sunda dalam mengelola alam sekitar, termasuk arah letak lahan pertanian yang harus terlebih dahulu mendapat sinar matahari, dan pemukiman sebaiknya melintang dari arah selatan menghadap ke utara. Pola pemukiman Sunda, terdapat pada naskah lontar Waruga Lemah (koleksi L622 koropak 88), naskah ini memaparkan pola topografi tanah dan wilayah pemukiman, pengaruh baik dan buruknya, berikut sarana dan mantra-mantra untuk mensucikannya. Pola topografi tanah juga terdapat pada naskah Sanghyang Siksa Kandang Karesian (SSKK) bagian keXXII. (Gunawan, 2010).

Baik prinsip purwadaksina maupun pola tofografi tanah dalam Waruga Lemah (bentuk tanah) dan Sanghyang Siksa Kanda ing Karesian (petunjuk menjadi Resi) memberikan wawasan dasar, bahwa lahan pertanian bersifat sakral sehingga harus di tempatkan pada area terbaik dalam arah yang utama. Nilai sakral muncul dari perlakukan manusia untuk memberikan energi terbaik dari sinar matahari kepada lahan huma. Sanghyang Siksa Kanda ing Karesian (SSKK) menyebutkan adanya struktur masyarakat Sunda yang dibagi dalam pola tiga (tiga gatra atau tritangtu), yaitu gatra Rama (karamaan-karamat), gatra Resi (karesian) dan gatra Ratu(karatuan; karaton). Trigatra RamaResi-Ratu, dalam naskah ini juga disebut dengan Wong Tani (Rama) - Wong Pandita (Resi) - Wong Prabu (Ratu), yang disebutkan memiliki ciri yang khas dalam tugas, wewenang dan kewajibannya.(Rusmana, 2018)

Dalam budaya Sunda yang berkembang di Ciptagelar Sukabumi Selatan, terdapat pola tiga atau tritangtu yang menunjukkan tiga hal yang mempengaruhi kehidupan di dunia, yaitu tekad (kehendak) - ucap (pikiran) - 
lampah (perbuatan atau tingkah laku). Dalam struktur organisasi kekuasaan Sunda buhun, terdapat pola tiga: resi-raturama, yang berarti: Resi adalah pendeta, Ratu adalah pemerintah, rama adalah rakyat. Resi ibarat air, ratu ibarat batu dan rama ibarat tanah.(Sumardjo, 2009)

Visi hidup masyarakat Sunda adalah mulasara buana (memelihara alam semesta) dengan misi Ngertakeun Bumi $L a m b a$ yaitu mensejahterakan kehidupan di dunia. Dari visi-misi masyarakat Sunda ini, diturunkan tugas kewajiban masingmasing gatra, yaitu: (1) Pakeun nanjeur najuritan (memenangkan pertempuran atau pertarungan) merupakan jalan ksatria (gatra ratu, prabu atau kaum bangsawan). (2) Pakeun mulasara titipan ti nu Rahayu (memelihara ajaran leluhur sebagai titipan dari Tuhan) untuk para resi atau pandita. (3) Pakeun heubeul jaya na buana (meraih kejayaan di dunia) adalah jalan untuk rakyat dalam mempertahankan kejayaan bangsa dan negara.(Putra, Kajian Bentuk dan Fungsi pada Kujang Huma Pamangkas, 2010), seperti tampak pada gambar 1 di bawah ini:

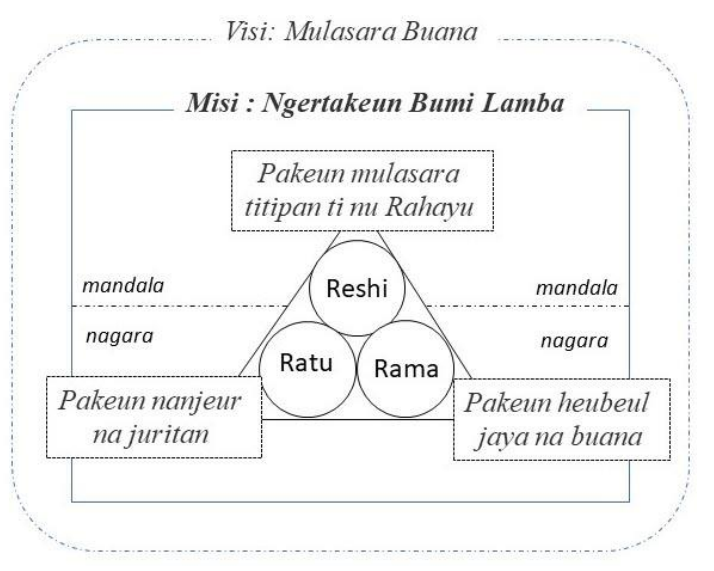

Gambar 1. Visi Misi Urang Sunda (visualisasi penulis)

Implementasi tugas "pakeun heubeul jaya na buana" dilaksanakan kaum rama dalam bentuk aktivitas meraih nafkah, untuk melanjutkan kehidupan dengan amal bakti (tapa) dalam hal memproduksi komoditas logistik, yaitu dengan bekerja sebagai pahuma, panyawah, pamayang (nelayan), pamatang (pemburu), palika (penyelam, pelaut) dan berbagai profesi lain yang menghasilkan pangan, sandang dan papan. Dalam budaya Sunda, suatu pekerjaan dinamai dengan istilah yang terkait dengan alam lingkungan yang ditandai dengan penggunaan peralatan kerja yang telah ditentukan oleh aturan adat (patikrama). Kelompok Rama atau pahuma atau wong tani, memiliki peralatan kerja sesuai dengan tugas dan kewajibannya masing-masing.

Naskah Sanghyang Siksa Kanda ing Karesian, menyebutkan secara eksplisit beberapa produk yang dirancang, dibuat dan diperuntukkan bagi masing-masing gatra, yang semuanya dibuat oleh Panday (pandai besi; paneupaan), yaitu:

"Sa(r)wa wir [a] ning teuteupaan ma tělu ganggaman palain. Ganggaman di Sang Prabu ma: pédang, abèt, pamuk, golok, peso teundeut, kěris. Raksasa pina[h]na dewana, ja paranti maehan sagala. Ganggaman Sang Wong Tani ma: kujang, baliung, patik, kored, sadap. Dětya pina[h]na dewana, ja itu paranti ngala kikicapeun iinumeun. Ganggaman Sang Pandita ma: kala katri, péso raut, péso dongdang, pangot, pakisi. Danawa pina[h]na dewana, ja itu paragi kumeureut sagala. Nya mana těluna ganggaman palain deui di sang prěbu, di sang wong tani, di sang pandita. Kitu lamun urang hayang nyaho disareanana, eta mo panday tanya". (segala macam tempaan, ada tiga macam yang berbeda. Pegangan sang prabu ialah: pedang, abet (cambuk), pamuk (gada), golok, peso teudeut (pisau belati; peso balapati), keris. Raksasa yang dijadikan dewanya, karena dipergunakan untuk membunuh. Pegangan petani ialah: kujang, baliung, patik, kored, pisau sadap. Detya dijadikan dewanya, karena digunakan untuk mengambil apa yang dapat dimakan dan diminum. Pegangan sang pendeta ialah: kala katri, peso raut, peso dongdang, pangot, pakisi. Danawa yang dijadikan dewanya, karena dipergunakan untuk mengerat segala 
sesuatu. Itulah segala jenis pegangan yang berbeda pada sang prabu, petani dan pendeta. Demikianlah bila kita ingin tahu, tanyalah panday besi). (Danasamita, 1987)

Tugas semua warga gatra Rama yang digambarkan sebagai rakyat dengan penghidupan sebagai petani, memiliki pegangan peralatan kerja yang terdiri dari (1) kujang, (2) baliung, (3) patik, (4) kored, (5) sadap. Urutan penyebutan dalam naskah tersebut memiliki tendensi sebagai urutan pekerjaan yang harus dilakukan oleh seorang petani huma atau pahuma. (Putra, Prosedur Ergonomi Dalam Patikrama Tatanen Huma Sunda, 2012). Seperti gambar 2 :

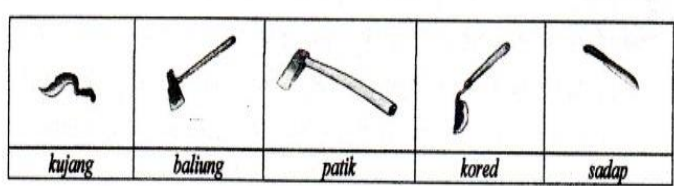

Gambar 2. Perkakas pertanian menurut Sanghyang Siksa Kanda ing Karesian sumber: visualisasi penulis

Pada interpretasi ini, kujang bukan senjata, karena sebagai senjata harusnya berada di gatra sang prabu seperti halnya keris, pedang, gada, cambuk dan pisau belati. Paparan eksplisit tentang kujang sebagai perkakas pertanian, dapat menjadi kontroversi, mengingat banyak budayawan Sunda yang meyakini bahwa kujang merupakan senjata pusaka khas Sunda.

Analisis yang dilakukan penulis dalam memaknai kujang sebagai salah satu perkakas pertanian, tergambar dari adanya kujang pamangkas atau sejenis congrang yang dipergunakan pahuma dalam membersihkan semak, rumput dan ranting di sekitar huma. (Putra, 2011).

Posisi peralatan pahuma untuk bekerja di huma, meliputi perkakas genggam yang dipakai dalam jarak dekat. Perkakas yang dipergunakan pada umumnya berukuran kecil sehingga dapat dipergunakan oleh kaum perempuan. Pahuma perempuan memiliki peran yang sangat penting dalam proses ngahuma, dan memiliki tugas khusus bersifat memuliakan kaum perempuan, yaitu antara lain pada proses ngaremokeun (memasukan bulir padi ke dalam lubang tanam) dan pembacaan mantera suci (Rohmana, 2014) Setiap perkakas diatur penggunaannya sesuai dengan sistematika kerja, jadwal kerja dan aturan ngahuma lainnya. digambarkan sebagai berikut:

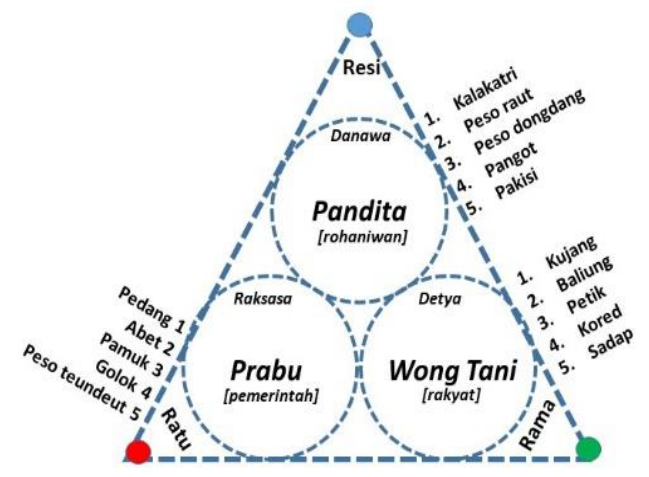

Gambar 3. Perkakas trigatra sumber: visualisasi penulis

Penggunaan perkakas pahuma mencakup sistematika kerja ngahuma, tampak pada tabel 1 berikut:

Tabel 1. Perkakas dan aktivitas ngahuma

\begin{tabular}{cl}
\hline Perkakas: & \multicolumn{1}{c}{ Kegiatan: } \\
Kujang & $\begin{array}{l}\text { Narawas, adalah ritual } \\
\text { permohonan ijin } \text { ngabukbak } \\
\text { (membuka hutan untuk huma), } \\
\text { melalui Bujangga yang } \\
\text { berpedoman pada kolenjer, untuk } \\
\text { menentukan waktu dan tempat } \\
\text { lahan. }\end{array}$ \\
\hline \multirow{3}{*}{ Baliung } & $\begin{array}{l}\text { Ngabukbak, membuka lahan awal } \\
\text { dengan baliung, membuat saluran } \\
\text { air atau batas lahan, memotong } \\
\text { perdu (mapas) sehingga lahan } \\
\text { huma bersih dari semak belukar. }\end{array}$ \\
\hline Patik & $\begin{array}{l}\text { Ngabukbak dan } \text { ngabaladah, } \\
\text { mempersiapkan lahan dengan } \\
\text { memotong pohon dengan patik } \\
\text { (kapak besar) di area tertentu } \\
\text { yang dijinkan. }\end{array}$ \\
\hline Kored & $\begin{array}{l}\text { Nyacar } \text { (membersihkan dan } \\
\text { memelihara } \text { huma dari rumput } \\
\text { dan perdu) }\end{array}$ \\
\hline Sadap & $\begin{array}{l}\text { Ngabuat } \text { atau proses panen padi } \\
\text { huma. } \text { Pisau sadap dipakai untuk }\end{array}$ \\
\hline
\end{tabular}


memotong jerami padi.

Siklus ngahuma yang berlaku di kawasan padukuhan, ditandai dengan ritual sebagai berikut pada tabel 2:

Tabel 2. Ritual dalam ngahuma

\begin{tabular}{cl}
\hline \multicolumn{1}{c}{ Ritual } & \multicolumn{1}{c}{ Makna } \\
\hline \multirow{4}{*}{ Ngukus } & $\begin{array}{l}\text { Bujangga (sesepuh pahuma) } \\
\text { menyajikan sasajen ka } \\
\text { karuhun (sesaji untuk leluhur) } \\
\text { disertai } \text { ngukus (menghadirkan } \\
\text { asap kemenyan menuju } \\
\text { mandala Hyang) }\end{array}$ \\
\hline & Memasukkan bulir padi ke \\
& dalam lubang hasil ngaseuk, \\
& merupakan simbol upacara \\
& perkawinan antara Nyi Pohaci \\
Ngaremokeun & Sanghyang Asri (Dewi Padi) \\
& dengan Batara Kuwera (Dewa \\
& Kemakmuran), sebagai \\
& visualisasi dari konsep lemah- \\
& cai (tanah air). \\
\hline \multirow{5}{*}{ Mitembeyan } & Membuat sesaji dan ngukus \\
& dengan membacakan mantera \\
& atau doa-doa untuk \\
& keberhasilan ngahuma dan \\
& kesejahteraan pahuma.
\end{tabular}

Siklus ngahuma ditandai dengan tahapan aktivitas yang didukung oleh beberapa ritual adat, baik yang bersifat ritual awal, ritual saat ngahuma dan ritual paska panen. Ritual syukuran misalnya dalam: kawalu, sěba, dan sěrěn taun. Siklus ini seperti gambar 4 di bawah ini:

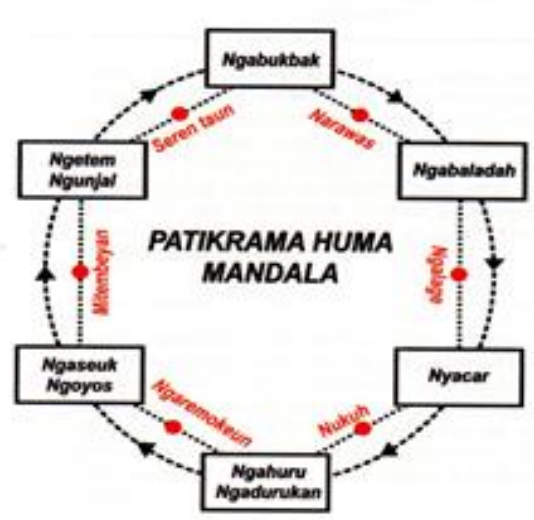

Gambar 4. Siklus Patikrama Huma Mandala (sumber: visualisasi penulis)
Berdasarkan siklus ngahuma sesuai dengan Patikrama huma, kegiatan ini dimulai dengan ngabukbak atau membuka hutan untuk lahan huma dengan terlebih dahulu mengadakan upacara ritual narawas (merintis dan menentukan lahan untuk huma). Pada acara narawas, pahuma menandai lahannya dengan batu, batu asahan, tanaman koneng (kunyit), atau tanaman hanjuang. Selama proses narawas, pahuma menahan diri untuk tidak berbicara kasar, kotor dan keras, selalu menggunakan baju yang bersih dan mengenakan ikat kepala.

Setelah hutan dibukbak, kemudian dilanjutkan dengan kegiatan ngabaladah (mempersiapkan lahan untuk huma) yang diresmikan dengan acara ngalage (hiburan rakyat yang disertai dengan agenda ritual religius, di kawasan kabuyutan muslim, ngalage berupa sawer sudat atau khitanan massal dengan seni jampana).

Setelah hutan dibaladah (dibersihkan dan dirapihkan), kemudian dilanjutkan acara nyacar yaitu membersihkan rumput, semak belukar dan pepohonan kecil yang tumbuh liar di lahan huma. Beberapa pahuma memotong beberapa dahan pohon besar untuk jalan masuk cahaya matahari memasuki area huma. Kegiatan ini dilakukan oleh seluruh anggota keluarga pahuma. Kegiatan ini dilakukan pada bulan kelima menurut pranatamangsa (lihat gambar 5). Setelah nyacar dilanjutkan dengan ritual nukuh, yaitu mengumpulkan rerumputan, perdu dan ranting pohon untuk dikeringkan secara alami dengan sinar matahari. Jika di lahan huma terdapat pohon besar atau pohon tua, maka dilakukan upacara penyampaian sesaji dan ucapan mantera agar para denawadan atau Detya penghuni pohon tidak marah tempatnya diganggu pahuma.

Rumput, semak dan ranting kering yang terkumpul kemudian dibakar pada acara ngahuru atau ngadurukan. Waktu ngaduruk berpatokan pada kehadiran bintang kidang, sesuai perintah "kidang ngarangsang kudu ngahuru" yaitu saat 
bintang kidang bercahaya terang di waktu subuh pada setiap tanggal 18 bulan ketujuh, merupakan saat paling tepat untuk membakar semak hasil nukuh.Pahuma berkewajiban menjaga api agar tidak membesar dan melebar, sehingga tidak menghadapi risiko kebakaran hutan. Setelah api padam sempurna, maka abu bekas bakaran ditebar sekitar huma sebagai pupuk alamiah.

Setelah lahan huma siap ditanami padi, maka memasuki tahap persiapan tanaman dan pemeliharaan huma, dengan diawali kegiatan nyo'o binih atau ngoyos, ngaseuk, ngirab sawan dan ngaremokeun (penanaman padi). Masa tanam disesuaikan dengan datangnya musim hujan dengan bintang kijang mencapai titik zenith pada waktu subuh yang disebut kidang muhunan. Nyo'o binih adalah kegiatan mempersiapkan benih padi yang dilakukan sebelum acara ngaseuk (proses pembuatan lubang tanam di area huma). Kegiatan nyo'o binih dimulai dengan menurunkan benih padi dari dalam lumbung padi. Kegiatan ini dilakukan oleh pahuma wanita. Pahuma wanita diwajibkan mengenakan baju putih, selendang putih, sabuk putih dan rambutnya disanggul rapi. Pahuma melakukan kegiatan itu dengan suasana yang sangat khidmat, tidak bercakap-cakap dan dengan merapalkan mantera, yang dimaknai sebagai upacara ritual untuk membangunkan Sanghyang Pwahaci Dewi Sri dari peraduannya.

Kegiatan berikutnya adalah ngaseuk yang berarti membuat lubang tanam dengan aseuk. Aseuk adalah potongan kayu atau bambu yang diruncingkan ujungnya untuk membuat lubang di dalam lahan huma. Ngaseuk dilakukan oleh pahuma pria dewasa, yang dimulai dari arah barat menuju timur atau mendekati arah cahaya matahari. Setelah lubang tanam siap, maka dilakukan acara ngaremokeun atau mempertemukan bibit padi dengan unsur tanah, yang disimbolkan sebagai perkawinan Dewi Sri dengan Dewa Bumi.
Acara menaburkan bibit bulir padi ke dalam lubang dilakukan oleh para pahuma wanita dewasa, dilakukan dari arah timur menuju barat, atau berjalan mundur menjauhi arah sinar matahari, dengan demikian pahuma dapat melihat lubang-lubang untuk ditanami padi dengan jelas dan benar. Proses ngaremokeun mirip dengan proses tanam mundur (tandur) dalam proses menanam padi di sawah. Pada saat ngaremokeun, para pahuma wanita merapalkan mantera khusus untuk mendoakan padinya tumbuh sehat dan subur.

Kegiatan paska ngaremokeun dilanjutkan dengan acara pemeliharaan tanaman padi agar tumbuh baik. Terkadang pahuma tinggal di dalam saung huma, untuk menjaga dan memelihara huma siang dan malam, dalam kegiatan yang disebut meuting atau bermalam di huma. Pada masa ini, padi huma masih rentan terhadap faktor cuaca, penyakit dan gangguan alami lainnya, sehingga diperlukan pahuma untuk menjaga, memperbaiki dan menanggulanginya. Kegiatan ini disebut ngirab sawan, yang secara harafiah berarti membuang sampah atau penyakit.

Dalam kegiatan ngirab sawan, pahuma melakukan pembersihan ranting,rumput,semak, atau tanaman lain yang berpotensi mengganggu pertumbuhan padi. Dalam acara ngirab sawan terdapat upacara ritual mengobati padi, yaitu memberikan tambahan nutrisi yang berasal dari ramuan adat yang terdiri dari campuran daun mengkudu, jeruk nipis, karuhang, areuy beureum, beuti lajo, gembol, hanjuang dan buah kelapa muda, yang ditumbuk halus dan dicampurkan dengan abu dapur atau abu hasil ngahuru yang disebarkan ke seluruh penjuru huma dengan melantunkan puisi atau pantun sakral. Upacara pengobatan atau pemberian nutrisi ini dilakukan sekira sepuluh kali selama pertumbuhan padi sampai siap panen.

Pada masa padi siap panen, dilakukan upacara Mipit yaitu kegiatan 
panen padi yang pertama kali dalam suatu musim, dan dilakukan secara simbolis oleh istri sesepuh adat. Padi hasil mipit ini bagian batangnya diikat dengan tali kulit pohon teureup pada bagian tangkainya sehingga menjadi satu ikatan (saranggeuyan). Ranggeuyan padi ini disemayamkan di saung huma dan setelah kering kemudian dibawa ke kampung untuk disimpan di leuit atau lumbung padi. Setelah melalui prosesi mipit, maka dilaksanakan panen padi bersama para pahuma yang disebut dibuat.

Dibuat adalah proses memanen padi dengan mempergunakan etem atau ani-ani, yang biasanya dilakukan oleh kaum wanita. Pelaksanaannya adalah setelah upacara mipit dan harus dilakukan secepatnya, sebab apabila terlambat memanen, maka konon hamawalang sangit (kungkang) akan muncul. Kegiatan dibuat tersebut dilakukan oleh seluruh keluarga pahuma, dan selama kegiatan tersebut sampai dengan padi menjadi kering dijemur, seluruh anggota keluarga menginap di huma. Kegiatan meuting di huma ini, merupakan salah satu peristiwa penting yang dipergunakan pahuma sepuh untuk mengajarkan tentang kosmologi Sunda kepada generasi mudanya.

Ngunjal adalah mengangkut hasil panen padi dari huma ke pemukiman untuk kemudian disimpan dalam leuit atau lumbung. Padi yang telah beberapa hari dikeringkan atau dilantay, kemudian disimpan tersusun dalam tumpukan yang teratur (dielep). Pengangkutan hasil panen dilakukan secara bertahap oleh seluruh keluarga pahuma. Para pahuma pria mengangkutnya dengan cara mengikat padi menjadi dua ikatan besar dan kemudian dipikul dengan menggunakan pikulan bambu, sedangkan para wanita membawa padi dengan cara menggendong dengan menggunakan kain. Setelah padi disimpan di leuit, para pahuma mempersiapkan upacara nganyaran, yaitu ritual syukuran dengan cara menikmati nasi hasil panen.
Nganyaran adalah kegiatan upacara memakan atau mencicipi nasi hasil dibuat di huma. Upacara nganyaran dimulai dengan mengambil lima ikat padi dari leuit, kemudian dibawa ke saung lisung, yaitu tempat menumbuk padi yang digunakan secara komunal. Padi ditumbuk oleh lima orang wanita tokoh masyarakat atau isteri sesepuh adat. Hal ini menggambarkan peran kaum ibu yang sangat strategis dalam masyarakat padukuhan.

Beras hasil tumbukan kaum ibu, disimpan dalam bakul nasi yang ditutup kain putih yang diberi wewangian, untuk dibawa ke rumah pemangku adat untuk diolah menjadi nasi tumpeng. Nasi tumpeng yang sudah siap dimanterai dan dipanjatkan doa oleh kepala padukuhan, untuk kemudian dibagikan kepada seluruh warga padukuhan.

Padi yang tersimpan dalam leuit merupakan stok pangan yang sangat penting dan strategis bagi masyarakat padukuhan, sehingga sangat dijaga dari gangguan hama dan unsur lain yang merusak padi. Padi yang dimiliki masyarakat untuk dikonsumsi khusus masyarakat padukuhan, sehingga tidak boleh dijual atau diperdagangkan.

Padi dari leuit merupakan milik komunal yang penggunaannya diatur menurut aturan adat. Jika terjadi musibah kekurangan pangan di tempat lain, masyarakat padukuhanakan dengan tulus memberikan bantuan pangan kepada yang tertimpa bencana. Prinsip ini menunjukkan adanya sistem manajemen logistik yang baik, dimana dengan mengatur penggunaan pangan untuk tidak dikonsumsi berlebihan dan tidak dijual untuk keperluan komersial, menjadikan masyarakat padukuhan memiliki ketahanan pangan yang sangat kuat.

Siklus ngahuma dengan ritual lengkap tersebut, hanya dilakukan oleh masyarakat Sunda di kawasan mandala. Kawasan mandala merupakan kawasan kasepuhan yang dianggap sakral, sehingga visi-misi Sunda dan konsep kehidupan 
tritangtu Rama-Resi-Ratu merupakan sistem yang terpadu dengan ritual huma dan pranatamangsa. (Saleh Danasasmita, 1986). Dalam Pranatamangsa, seluruh tahapan pekerjaan ngahuma dilakukan secara konsisten dan terpadu dengan memperhatikan ekosistem. Seperti pada gambar 5 di bawah ini:

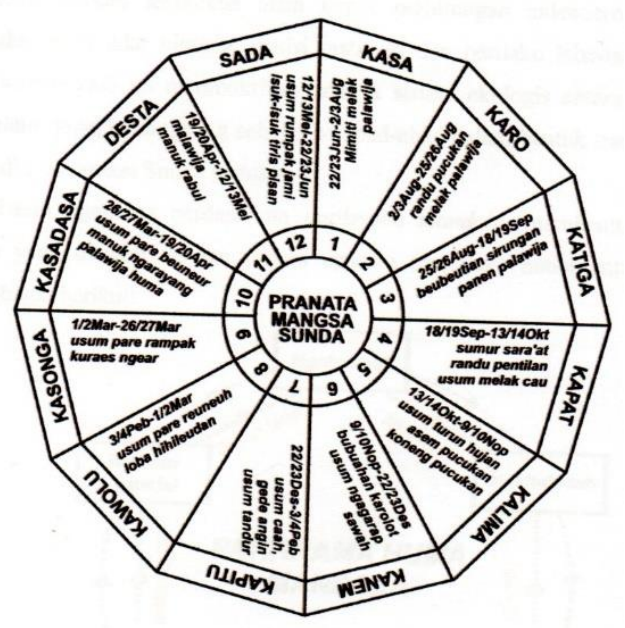

Gambar 5. Pranatamangsa Huma Sunda sumber: visualisasi penulis

\section{B. METODE PENELITIAN}

Penelitian mengenai Patikrama Tatanen Huma Sunda ini mempergunakan pendekatan kualitatif, karena memfokuskan pada analisis data yang sifatnya deskriptif. Data-data yang diperoleh dari sumber primer, diperoleh melalui pengamatan, wawancara dan partisipasi subjek.(Spradley, 2007).

Sistematika pengamatan, wawancara dan partisipatori ini digambarkan seperti skema interaksi science-culture-techno yang diperoleh dari pendekatan etnografis dengan fokus budaya untuk mengetahui apa yang dikerjakan masyarakat, pendekatan partisipatori dengan fokus teknologi apa yang dikerjakan masyarakat, serta pendekatan etnografis dengan fokus sains untuk memahami apa yang mereka kerjakan. Seperti pada gambar 5:

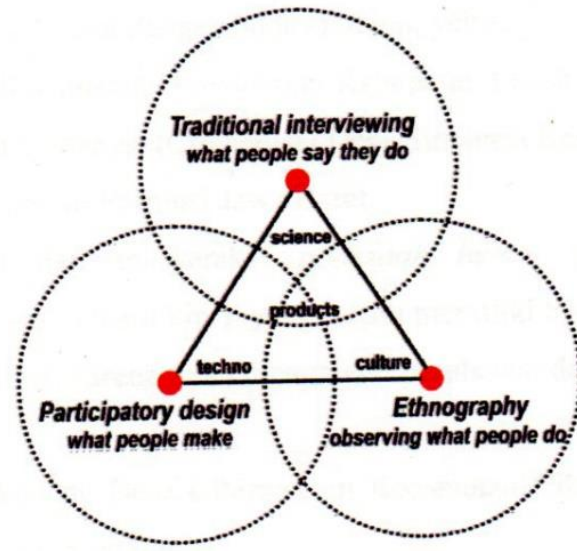

Gambar 6. Skema metode etnografi (elaborasi penulis dari situs: http://www.yainal.web.id)

Subjek penelitian untuk pengamatan dan wawancara adalah para pahuma aktif, yang terdiri dari dua katagori, yaitu:

(A). Kelompok pahuma dari masyarakat padukuhan, yaitu komunitas masyarakat kasepuhan atau kabuyutan yang memegang teguh tradisi buhun. Terdapat dua sampel padukuhan yang sangat populer, yaitu: 1. Desa Kaněkěs Kecamatan Leuwidamar Kabupaten Lebak Propinsi Banten, 2. Kampung adat Ciptarasa (Ciptagelar) Desa Sirnarasa Kecamatan Cisolok Kabupaten Sukabumi Propinsi Jawa Barat.

(B). kelompok pahuma dari masyarakat padesaan, yaitu komunitas masyarakat desa hutan di masa kini yang masih mengelola huma, yaitu: 1. Kampung Cikoneng Desa Cibiru Wetan Kecamatan Cileunyi Kabupaten Bandung Provinsi Jawa Barat, 2. Dusun Karangsari Desa Cibeureum Kecamatan Sukamantri Kabupaten Ciamis Provinsi Jawa Barat.

Informasi dari kedua kelompok pahuma diperoleh melalui wawancara langsung (direct interview) dengan beberapa orang pahuma di lahan huma, yang dilengkapi dengan pengamatan lapangan (fieldwork observation) terhadap perilaku pahuma sebagai subjek dan situasi ekosistem huma sebagai objek.

Melalui wawancara secara acak dengan beberapa subjek sampel di Kampung Cikoneng dan Dusun 
Karangsari, diperoleh ragam informasi pengetahuan ngahuma yang berkembang di pedesaan. Wawancara dengan sesepuh adat dan tokoh masyarakat pahuma pedesaan, dilakukan untuk mengetahui dasar-dasar budaya Sunda yang berkembang di masing-masing desa. Dari kedua desa ini, kemudian dilakukan analisis komparasi dengan data yang diperoleh dari masyarakat padukuhan, setelah sebelumnya juga dikomparasikan dengan masing-masing padukuhan sampel, guna mengetahui kecenderungan perubahan dan signifikansi perbedaan satu sama lain.

\section{HASIL DAN BAHASAN}

Berdasarkan wawancara etnografis (ethnographic Interview) dan observasi lapangan (fieldwork observation) terhadap beberapa subjek penelitian yang terdiri dari para pemangku adat Sunda dan para pahuma di dua katagori masyarakat Sunda, yaitu: masyarakat padukuhan yang tradisional konservatif dan masyarakat pedesaan yang cenderung moderat.

Kegiatan observasi dan interview ini lebih banyak dilakukan di kelompok masyarakat pedesaan yang belum banyak diteliti dan dipublikasikan, sedangkan data tentang padukuhan kasepuhan mandala (desa adat) lebih banyak dikaji oleh para peneliti dari berbagai susdut pandang keilmuan, sehingga terdapat beberapa publikasi yang dapat dijadikan referensi, karena berisi informasi tentang kampung kasepuhan atau desa padukuhan dengan sangat lengkap.

Melalui analisis komparatif antara kelompok padukuhan (desa mandala) dengan padesaan (desa nagara atau desa non-mandala), diperoleh gambaran tentang perbedaan kehidupan yang terdapat di kedua katagori masyarakat Sunda. Gambaran ini merupakan fakta telah terjadi perubahan dan perkembangan budaya dan kecenderungan perubahan lainnya di masyarakat Sunda.

Kegiatan ngahuma di huma mengalami perkembangan dan perubahan nilai di kawasan padesaan, karena mengalami inkulturasi dengan kebudayaan lain. Pedesaan yang menetap dan berada di kawasan subur dengan prinsip lemah-cai (tanah air), yaitu tanah yang mudah ditanami dan air yang mengalir sepanjang tahun. Padesaan memilih tempat yang terdekat dengan sumber air, seperti sungai dan danau.

Pedesaan sangat menghormati air (cai atau ci), sehingga menjadikan kawasan berair sebagai nama dusun atau nama desa. Seperti: Cicadas, Cikoneng, Ciherang, Cihideung, Cibiru, dan berbagai nama dengan imbuhan $C i$ di depannya. Pedesaan yang berada di lingkungan air melimpah, meyakini bahwa sawah merupakan pilihan terbaik daripada huma.

Para petani huma yang berubah menjadi petani sawah (panyawah), masih terkait dengan misi gatra Rama, yaitu: Pakeun heubeul jaya na buana (meraih kejayaan di dunia) sebagai jalan untuk rakyat dalam mempertahankan kejayaan bangsa dan negara. Panyawah mampu meningkatkan ketersediaan pangan yang melimpah, sehingga menjadikan desa sebagai basis logistik yang penting dalam meningkatkan kemajuan bangsa dan negara. Oleh karena itu, tugas penyawah dan pahuma di desa, disebut sebagai tugas tapa di nagara.

Perbandingan cara pandang masyarakat pahuma di kawasan padukuhan dan kawasan padesaan, sebagai berikut:

Tabel 3. Komparasi Paradigma Huma

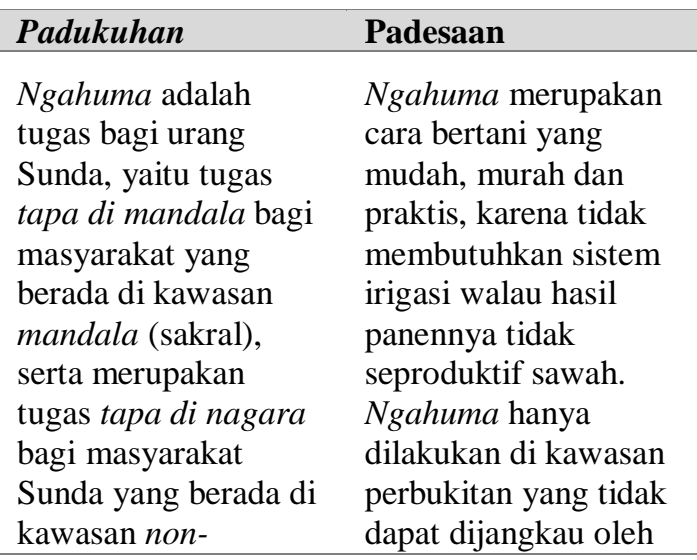




$\begin{array}{ll}\begin{array}{l}\text { mandala atau } \\ \text { padesaan. }\end{array} & \text { saluran air. } \\ \text { Ngahuma dilakukan } & \text { Sistem } \text { ngahuma yang } \\ \text { di Leuweung } & \text { berupa tumpang sari, } \\ \text { Garapan } \text { (Hutan } & \text { yaitu tanam padi di } \\ \text { Lindung) dengan } & \text { antara pepohonan di } \\ \text { siklus huma yang } & \text { kawasan hutan, dan } \\ \text { teratur sesuai } & \text { tidak mengikuti aturan } \\ \text { patikrama ngahuma } & \text { daur siklus huma } \\ \text { sebagai ketetapan } & \text { mandala. } \\ \text { adat. Kegiatan } & \text { Ngahuma merupakan } \\ \text { menanam padi di } & \text { pilihan terakhir, jika } \\ \text { sawah atau nyawah, } & \text { syarat untuk } \\ \text { adalah kegiatan yang } & \text { pencetakan sawah } \\ \text { diharamkan, karena } & \text { tidak dapat dipenuhi. } \\ \text { cenderung merusak } & \\ \text { alam. } & \end{array}$

Aturan padukuhan yang mengharamkan sawah yang dianggap berkecenderungan merusak ekosistem, sepertinya mengalami kontroversi, karena ada beberapa padukuhan yang justeru mengembangkan sawah sebagai kegiatan utama.

Salah satu padukuhan yang memiliki patikrama tatanen yang mengatur kawasan sawah untuk masarakat paling luar dan kawasan huma sakral di lingkungan dalam, adalah Kampung Kasepuhan Cipta Gelar. Masyarakat Adat Cipta Gelar menggarap sawah dan ladang sesuai dengan kondisi geografisnya, yaitu: jika tersedia aliran air yang berlimpah maka di area itu dibuat sawah dan kolam ikan, sedangkan di area yang tidak memiliki sumber air merupakan kawasan huma dan kebun palawija.

Beberapa padukuhan yang mengandalkan sawah dalam bercocok tanam dan memperoleh pangan, diantaranya adalah: Kampung Naga, Kampung Cikondang dan Kampung Dukuh.

Selain itu ada juga padukuhan yang justru tidak mengkonsumsi padi, sehingga tidak ada sawah maupun huma, yaitu: Kampung Adat Cireundeu, yang terletak di Kelurahan Leuwigajah Kecamatan Cimahi Selatan Kotif Cimahi. Masyrakat Kampung Cireundeu hanya mengkonsumsi ketela pohon atau singkong.
Berdasarkan pengamatan terhadap lokasi geografis pada masing-masing kampung adat kasepuhan atau padukuhan, terdapat suatu kesepakatan untuk mengembangkan pemukiman sesuai dengan situasi dan kondisi alam lingkungannya. Jika berada pada dataran tinggi yang tidak terdapat sumber air yang berlimpah dan hanya mengandalkan air hujan dan embun, maka wilayah itu relevan untuk dijadikan kawasan huma. Sedangkan jika lokasi kampung berada di kawasan sumber air dan tidak mengandalkan hujan, maka menjadi kawan sawah terasering maupun sawah datar.

Keberadaan lokasi huma di suatu wilayah padukuhan maupun padesaan, sangat terkait dengan kondisi geografis, hal ini sesuai dengan kemampuan masyarakat Sunda yang mudah beradaptasi dengan lingkungannya. Kearifan lokal yang dimiliki setiap masyarakat padukuhan maupun padesaan, merupakan hasil pengalaman panjang dalam memperjuangkan kehidupan di kawasan yang dipilihnya.

Observasi yang dilakukan terhadap kegiatan huma di beberapa pedesaan di Jawa Barat, memperlihatkan huma sebagai akibat kondisi geografis. Sebagai berikut:

\section{Huma di Desa Cibiru Wetan}

Observasi terhadap Desa Cibiru Wetan dilaksanakan secara langsung selama tiga bulan, meliputi pengamatan terhadap kondisi huma, perilaku pahuma, dan kegiatan ngahuma. Desa Cibiru Wetan secara geografis terletak di kawasan Gunung Manglayang, didominasi oleh perbukitan dan dataran tinggi. Luas desa mencapai 295 hektar, dengan area tegalan atau ladang huma mencapai 153,5 hektar (45.93\%). Huma terbentang di sekitar puncak Gunung Manglayang sampai kaki gunung yang berbatasan dengan beberapa pemukiman.

Dinas Perhutani Provinsi Jawa Barat bersama para pahuma, bekerjasama mengelola kelestarian hutan lindung di wilayah ini, yaitu Hutan Gunung 
Manglayang. Kesepakatan antara pemerintah (Dinas Perhutani) dengan masyarakat petani huma, adalah untuk mentaati peraturan hak guna hutan lindung di sekitar Gunung Manglayang, antara lain: (1). Tidak boleh menebang pepohonan yang ada di sekitar hutan lindung. (2). Warga diperkenankan mengambil dan memanen buah-buahan dan perdu yang dipelihara di sekitar hutan lindung, dengan catatan hasilnya dibagi dua dengan Dinas Perhutani, (3) pepohonan buah yanag ada di daerah perbatasan (antara hutan lindung dan pemukiman penduduk) terlarang ditebang, tetapi buahnya dapat dimiliki oleh warga setempat.

Area ladang di kaki Gunung Manglayang ini sangat unik, terletak di kemiringan yang tajam dengan pepohonan kayu yang rimbun. Seperti sistem tumpang sari, di bawah pepohonan itu dibudidayakan tanaman padi huma (2 ha), cabai (5 ha), kacangtanah (35 ha), jagung (80 ha) dan sayuran (25.5 ha). Jenis huma yang ada di desa ini pada umumnya merupakan huma tetap.

Menurut pahuma Desa Cibiru Wetan, pola lama dimana huma berpindah sudah lama ditinggalkan, berganti dengan sistem baru yaitu: setelah panen, lahan huma dianggap tidak subur sehingga dibiarkan terlantar untuk beberapa musim, sampai siap digarap kembali dengan membersihkan semak belukar. Huma yang bala (ditumbuhi semak belukar) disebut reuma, pembersihannya disebut ngareuma.

Proses ngahuma di Desa Cibiru Wetan terdiri dari empat tahap, yaitu:

1. Tahap pengolahan tanah, terdiri dari enam proses :

a. ngaresik atau membersihkan lahan dari semak dan rerumputan, dengan perkakas tebas seperti congkrang dan parang,

b. nguyab atau pembakaran semak dan rumput hasil ngaresik,

c. ngeprek atau proses penggemburan tanah dengan cangkul di permukaan tanah,

d. ngagaritan atau memetakan tanah, e. Ngalobang yaitu membuat lubang untuk memasukkan pupuk.

2. Tahap penanaman, dilakukan dengan ngaseuk atau membuat lubang untuk memasukkan benih padi. Dilakukan oleh pahuma pria dan wanita.

3. Tahap pemeliharaan tanaman: ngabaladah atau ngored membersihkan rumput dengan kored dan ngarabas atau menjaga tanaman dari penyakit dan hewan liar.

4. Tahap panen atau pengumpulan hasil tanam, dengan mempergunakan ketam dan arit.

Pahuma di Desa Cibiru Wetan memiliki kebiasaan menanam aneka jenis tanaman di sekitar tanaman padi, seperti kunyit, gandum, kacang kedelai dan jagung, sehingga hasil panennya sangat beragam. Dalam kegiatan ngahuma ini, tidak ditemukan adanya upacara atau ritual adat apapun.

Desa Cibiru Wetan merupakan desa gersang yang hanya memiliki beberapa mata air dari Gunung Manglayang, yang pada umumnya merupakan sumur artesis yang berada di kawasan lembah dan ngarai. Air dari kedalaman lembah ini disalurkan untuk suplai air bagi beberapa pemukiman atau perumahan baru. Di bagian atas Desa Cibiru Wetan, adalah Desa Cikoneng I-III, yang terletak di kaki Gunung Manglayang, ketiga desa ini mendapatkan banyak sumber air gunung, tetapi tidak memiliki sawah. Masyarakat desa ini hidup sebagai peternak, pahuma dan pekebun palawija dan komoditi sayuran. Namun uniknya, hampir semua huma berada sangat dekat dengan wilayah desa Cibiru Wetan.

Desa Cibiru Wetan merupakan contoh kawasan pedesaan di Jawa Barat yang masih memiliki huma. Kegiatan ngahuma yang berlangsung memiliki perbedaan dengan siklus ngahuma yang berlaku di Padukuhan.

\section{Huma di Dusun Karang Sari}

Dusun Karang Sari, Desa Cibeureum Kecamatan Sukamantri (Panjalu Utara) 
Kabupaten Ciamis, memiliki keunikan dalam mengelola huma. Pahuma dari dusun ini sebetulnya adalah panyawah juga, pada umumnya memiliki kluster huma di antara kebun talun dan lahan pesawahan. Area huma pada umumnya menyatu dengan area kebun. Huma secara khusus ditemukan di kawasan perbatasan hutan lindung.

Kawasan leuweung (hutan) di desa ini sangat terjaga dari eksplorasi dan ekploitasi yang berlebihan, sehingga lebatnya hutan belantara memperlihatkan ekosistem sangat terjaga baik. Dari kawasan desa hutan ini, lahir kesenian unik berupa seni arak-arakan Bebegig Sukamantri, sejenis ondel-ondel yang menunjukkan topeng muka siluman dengan asesoris dan atribut dari bahan alamiah yang tersedia di hutan. Bebegig ini divisualisasikan sebagai penjaga hutan lindung, yang muncul dalam karnaval di berbagai acara besar, termasuk upacara nyangku dan HUT kemerdekaan RI.

Bebegig Sukamantri merupakan simbol pelestarian hutan. Pada kepercayaan buhun masyarakat Kecamatan Sukamantri (Panjalu Utara) bahwa bebegig ini merupakan simbol atau visualisasi denawa penjaga hutan. Dalam buku Sanghyang Siksa Kanda ing Karesian, denawa diartikan sebagai jenis dewa atau siluman yang berada di kawasan hutan, yang menjadi tanggungjawab wong tani (pahuma; gatra rama) dalam mengelola lingkungan untuk menghasilkan makanan dan minuman.

Denawa digambarkan memiliki wajah yang menyeramkan, sebagai bentuk visualisasi yang berbeda dengan wajah dewa-dewi atau batara-betari yang pada umumnya berwarna tampan atau cantik jelita. Seperti digambarkan dalam Wayang Golek Sunda, batara dan betari selain berwajah tampan atau cantik juga berhati baik, tetapi ada kalanya wajah rupawan berubah menjadi buruk rupa dan jahat. Sebaliknya, denawa yang buruk rupa sering digambarkan sebagai sosok jahat, yang bisa berubah menjadi sosok yang indah dan rupawan dengan hati yang mulia.

Konsep dunia paradoks ini merupakan salah satu ciri umum yang terdapat dalam ragam kebudayaan Sunda. Sebagai bentuk pembelajaran bagi umat manusia, bahwa untuk tidak hanya memandang dari sisi luar tetapi harus juga paham dari sisi dalamnya. Filosofi ini berlaku dalam memaknai gunung yang berarti giri (gunung secara fisik, serta gunung yang dimaknai guru nu agung. Gunung pada jaman dulu merupakan universitas atau pusat pengembangan ilmu pengetahuan, sehingga banyak kawasan mandala dan kawasan mulia, berada di puncak-puncak gunung.

Pahuma yang hidup di kawasan gunung, merupakan sosok yang tangguh dan memiliki keterampilan yang sangat tinggi. Kemampuan adaptifnya di lingkungan hutan, menjadikan pahuma lebih memahami lingkungan hutan daripada masyarakat lain. Pahuma memiliki kecerdasan dalam memaknai lingkungan, cuaca dan musim, mampu bertahan terhadap serangan hewan buas dan menjadi dukun tani.

Inilah tampilan bebegig Sukamantri yang menjadi ikon penjaga hutan di kawasan Panjalu Jawa Barat:

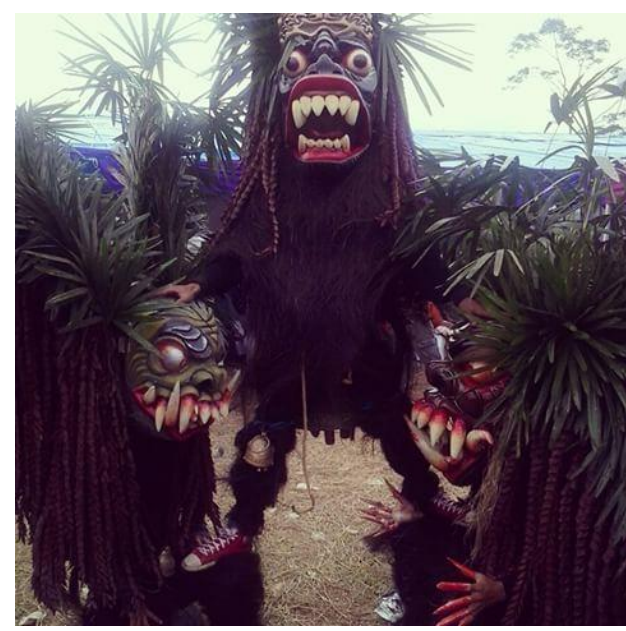

Gambar 7. Contoh Bebegig Sukamantri sumber: koleksi penulis 
Klaster huma di Dusun Karang Sari merupakan jenis huma yang fleksibel, yaitu dapat berubah menjadi sawah maupun kebun. Huma di dusun ini tidak pernah menjadi reuma. Menurut sesepuh dusun, di masa lalu huma di kawasan Panjalu terletak di atas bukit dan di dalam hutan, namun sedikit demi sedikit jumlahnya menyusut drastis, akibat berkembangnya sistem sawah yang lebih produktif. Secara geografis, wilayah ini sangat sesuai untuk lahan sawah daripada huma, karena wilayah terluas merupakan kawasan tanah datar yang tersuplai air pegunungan secara alamiah.

Proses ngahuma di Dusun Karang Sari terdiri dari empat tahap, yaitu:

1. Tahap pengolahan tanah, terdiri dari empat proses :

a. mangkas atau ngored atau ngarit yaitu membersihkan lahan dari semak sesuai dengan alat yang dipakai. Mangkas mempergunakan parang pangkas, ngored pakai kored, ngarit pakai arit.

b. ngadurukan atau pembakaran semak dan rumput hasil mangkas/ngored/ngarit.

c. ngeprek atau proses penggemburan tanah dengan cangkul di permukaan tanah,

d. ngagaritan atau memetakan tanah,

2. Tahap penanaman, dilakukan dengan ngaseuk atau membuat lubang untuk memasukkan benih padi.

3. Tahap pemeliharaan tanaman: ngored membersihkan rumput dengan kored dan ngarokut atau menggunakan alat bernama rokut (berasal dari ngagaro jukut atau menggaruk rumput).

Tahap panen atau pengumpulan hasil tanam, dengan mempergunakan ketam dan arit. Sekam dan jerami padi paska panen dijadikan pakan ternak.

Huma di Dusun Karang Sari Desa Cibeureum Kecamatan Sukamantri Kabupaten Ciamis, merupakan contoh huma yang berada di kawasan dataran rendah atau kawasan persawahan. Situasi huma ini tidak terkait dengan kondisi geografis, sehingga sangat mengherankan, mengapa ada huma di wilayah persawahan yang subur dan air berlimpah.

Berdasarkan interview dengan pemuka desa, huma di Dusun Karang Sari merupakan jenis kluster huma yang tidak terkait dengan situasi dan kondisi geografis. Hal itu terjadi karena banyak petani sawah yang merindukan padi huma yang bulirnya lebih besar dan lezat. Jika terjadi musim kemarau yang panjang dan sumber air menyusut, klaster huma mampu menjadi solusi terbaik, sehingga petani tidak sangat rugi akibat gagal panen di pesawahan. Tanaman padi huma yang ditanam di pekarangan rumah masyarakat Dusun Karang Sari, memperlihatkan nuansa yang berbeda tentang tampilan huma yang biasanya berada di tempat terpencil yang jauh dari pemukiman.

Dalam masyarakat Sunda, istilah pajauh huma atau humanya berjauhan, masih membekas dan mendalam sebagai bentuk peringatan kepada sanak saudara yang bertengkar atau berselisih paham yang berkepanjangan. Memiliki huma yang berjauhan padahal bersaudara, merupakan hal yang ditakuti atau dihindari, bahkan menjadi kata negatif yang bermakna kutukan. "ulah pasea wae bisi pajauh huma" merupakan kalimat umum yang sering diucapkan orang tua kepada anak-anaknya.

Huma di Dusun Karang Sari merupakan visualisasi dari upaya untuk meningkatkan persaudaraan, perdamaian dan kesabaran untuk mencapai kebajikan keluarga. Huma yang dibuat di pekarangan rumah, memberikan gambaran pula bahwa nilai-nilai kehidupan di huma dapat diambil hikmahnya untuk dilestarikan dalam kehidupan di pedesaan.

Sebagai makhluk sosial, orang Sunda dapat mengembangkan berbagai bentuk agroekosistem seperti berladang, bercocok tanam, membuat pekarangan dan berkebun sayuran. (Johan Iskandar, 2015)

Kemampuan petani di kawasan desa hutan masa kini, merupakan kemampuan dan keterampilan yang diwariskan secara 
turun temurun dari leluhurnya yang bekerja sebagai pahuma. Pencak silat yang dilestarikan di Desa Cibeureum juga merupakan warisan dari kemampuan pahuma melawan harimau maupun binatang buas yang banyak ditemukan di hutan belantara Panjalu.

Perhatian pahuma kepada ekosistem hutan, terwujud dari kemampuannya menjaga hutan dari berbagai anasir yang membahayakan hutan. Dengan demikian pelestarian hutan dapat dioptimalisasikan dengan menampilkan peran pahuma.

\section{Komparasi Kegiatan Huma di Padukuhan dan Pedesaan}

Proses kegiatan ngahuma di Padukuhan dan Pedesaan, dapat dilihat dari adanya siklus huma yang menjadi S.O.P (Standar operational procedure) atau Patikrama Tatanen Huma Sunda. Siklus huma merupakan peristiwa pengelolaan huma mulai dari persiapan lahan sampai panen padi. Pada tabel 4 diperlihatkan komparasi siklus huma, yang merupakan aktivitas ngahuma yang dapat diamati guna melihat kecenderungan perubahan perilaku.

Tabel 4. Komparasi Siklus Huma

\begin{tabular}{|c|c|}
\hline $\begin{array}{l}\text { Siklus Huma } \\
\text { Padukuhan }\end{array}$ & $\begin{array}{l}\text { Siklus Huma } \\
\text { Padesaan }\end{array}$ \\
\hline $\begin{array}{l}\text { Dasar siklus huma } \\
\text { mengikuti patikrama } \\
\text { tatanen huma Sunda, } \\
\text { sebagai acuan } \\
\text { mulasara buana } \\
\text { dengan semangat tapa } \\
\text { di mandala. Meliputi } \\
\text { siklus: narawas } \rightarrow \\
\text { ngabukbak } \rightarrow \\
\text { ngabaladah } \rightarrow \\
\text { nyacar } \rightarrow \text { nukuh } \rightarrow \\
\text { ngahuru } \rightarrow \text { ngaseuk } \\
\rightarrow \text { ngoyos } \rightarrow \text { ngunjal } \\
\rightarrow \text { ngareuma. }\end{array}$ & $\begin{array}{l}\text { Siklus ngahuma } \\
\text { cenderung terbentuk } \\
\text { dari manifestasi } \\
\text { kebutuhan dan } \\
\text { ketersediaan pangan } \\
\text { dan optimalisasi } \\
\text { lahan. Terdiri dari } \\
\text { siklus: ngabaladah } \rightarrow \\
\text { nyacar } \rightarrow \text { ngaseuk } \rightarrow \\
\text { ngoyos } \rightarrow \text { ngaduruk }\end{array}$ \\
\hline
\end{tabular}

Siklus huma di pedesaan tidak mengenal patikrama tatanen huma, cenderung lebih ringkas untuk produktivitas ekonomis dan efisiensi kerja.
Hal ini terlihat dari tiadanya upacara ritual yang terkait dengan proses ngahuma.

Selain karena faktor Agama Islam yang melarang penganutnya untuk kembali memahami animisme-dinamisme dan ajaran lainnya, para pahuma di pedesaan yang sebagian besar adalah kaum muslimin, telah menjadikan siklus menanam padi bukan merupakan peristiwa yang sakral.

Visi ngahuma dalam masyarakat Padukuhan sebagai bentuk memelihara alam lingkungan (mulasara buana), dikembangkan di masyarakat pedesaan dengan menjadikan huma sebagai alternatif terbaik dalam bercocok tanam padi di lahan kering, hutan atau kawasan sawah yang tidak dapat dialiri irigasi.

Prospek ngahuma di kawasan hutan tropis, dikembangkan masyarakat pedesaan dengan mengacu pada keberhasilan masyarakat Padukuhan menjaga ekosistem hutan. Hutan desa menjadi bagian sangat penting bagi kehidupan masyarakat desa, sehingga eksploitasi yang berlebihan, pembabatan hutan, pembakaran hutan, dan pembuatan kebun monokultur, dapat merugikan petani pedesaan secara langsung.

Di kawasan desa hutan masa kini, seperti yang terjadi di Desa Cibeureum Ciamis, yang dicanangkan Menteri Pertanian RI sebagai kawasan agropolitan (agribisnis dan agrowisata), mengalami dilema akibat terjadinya proses deforestri (pembabatan hutan untuk lahan pertanian), sehingga bukit atau gunung menjadi gundul dan hanya ditanami komoditas sayuran yang rentan terhadap erosi. Keberhasilan agribisnis modern yang membutuhkan lahan pertanian yang luas, terkadang mengharuskan hutan diubah menjadi kebun.

Pola perilaku pahuma Padukuhan dilandasi oleh adanya patikrama yang mengharuskan pahuma bersikap paripurna terhadap alam sekitarnya. Banyak pahuma yang sangat arif membiarkan humanya diserbu burung tanpa berusaha mengusirnya. Pahuma meyakini bahwa 
burung yang datang mungkin memakan ulat atau hama, bukan semuanya makan bulir padi.

Pahuma di padukuhan tidak pernah mengusir atau mengganggu jalur babi hutan, mereka percaya babi hutan yang melewati huma tidak akan merusak huma, justru memberikan manfaat dengan secara tidak langsung memberikan pupuk organik di sekitar huma.

Perilaku menarik dari pahuma Padukuhan adalah memperlakukan tanaman padi dengan sangat hormat. Padi yang akan dipanen tidak boleh dipangkas dengan parang atau arit dengan tenaga kuat, karena dimungkinkan di sekitar padi yang akan dipotong terdapat sarang burung.

Perilaku pahuma Padesaan memiliki perspektif yang berbeda. Berikut ini adalah komparasi dinamika perilaku pahuma antara pahuma di Padukuhan dengan pahuma di Pedesaan sebagai berikut:

Tabel 4. Komparasi dinamika perilaku pahuma

\begin{tabular}{|c|c|}
\hline $\begin{array}{l}\text { Perilaku pahuma } \\
\text { padukuhan }\end{array}$ & $\begin{array}{c}\text { Perilaku pahuma } \\
\text { pedesaan }\end{array}$ \\
\hline $\begin{array}{l}\text { Pahuma di } \\
\text { padukuhan } \\
\text { melakukan kegiatan } \\
\text { ngahuma sebagai } \\
\text { bentuk tugas hidup } \\
\text { (tapa di mandala) }\end{array}$ & $\begin{array}{l}\text { Pahuma di pedesaan, } \\
\text { ngahuma untuk } \\
\text { bertahan hidup. } \\
\text { Pahuma memilih } \\
\text { huma sebagai solusi } \\
\text { bertani murah dan } \\
\text { mudah }\end{array}$ \\
\hline $\begin{array}{l}\text { Patikrama huma } \\
\text { sebagai SOP }\end{array}$ & $\begin{array}{l}\text { Pahuma desa tidak } \\
\text { memilki SOP }\end{array}$ \\
\hline $\begin{array}{l}\text { Visi ngahuma adalah } \\
\text { mulasara buana }\end{array}$ & $\begin{array}{l}\text { Visi ngahuma desa } \\
\text { adalah memanfaatkan } \\
\text { lahan tani dengan } \\
\text { investasi murah }\end{array}$ \\
\hline $\begin{array}{l}\text { Misi pahuma adalah } \\
\text { tapa di mandala, } \\
\text { untuk ngertakeun } \\
\text { bumi lamba. }\end{array}$ & $\begin{array}{l}\text { Misi ngahuma untuk } \\
\text { mengembangkan } \\
\text { metode bertani lahan } \\
\text { kering sebagai sumber } \\
\text { pangan }\end{array}$ \\
\hline $\begin{array}{l}\text { Padi adalah sakral, } \\
\text { pola respek terhadap } \\
\text { Nyi Pohaci } \\
\text { Sanghyang Asri } \\
\text { (Dewi Sri) }\end{array}$ & $\begin{array}{l}\text { Padi huma adalah } \\
\text { komoditi pangan yang } \\
\text { dapat dibudidayakan } \\
\text { untuk peningkatan } \\
\text { nilai ekonomi }\end{array}$ \\
\hline Patuh pada & Pola ngahuma \\
\hline
\end{tabular}

\begin{tabular}{ll}
\hline pranatamangsa & $\begin{array}{l}\text { berdasarkan kondisi } \\
\text { cuaca dan karakter } \\
\text { ekosistem }\end{array}$ \\
\hline
\end{tabular}

Perilaku pahuma padesaan cenderung menggarap huma sebagai sarana untuk memenuhi kebutuhan pangan. Terdapat aturan desa untuk melestarikan hutan dan ekosistem, sehingga tidak terjadi perusakan hutan dan penebangan liar yang berakibat bencana alam.

Pemanfaatan lahan hutan utuk penanaman padi huma, merupakan kreasi yang unik dan sangat bermanfaat untuk masa depan petani di kawasan desa hutan. Konsep petani huma yang memanfaatkan ruas antar pohon sebagai jalur tanaman padi huma, merupakan sistem huma yang berbeda dengan patikrama huma yang berlaku di padukuhan.

Berikut ini adalah hasil komparasi penggunaan perkakas pertanian di huma padukuhan dan huma padesaan, sebagai berikut:

Tabel 5. Komparasi penggunaan perkakas tani

\begin{tabular}{|c|c|}
\hline $\begin{array}{c}\text { Perkakas } \\
\text { Padukuhan }\end{array}$ & Perkakas Pedesaan \\
\hline $\begin{array}{l}\text { Perkakas ngahuma } \\
\text { terdiri dari } \\
\text { peralatan kerja } \\
\text { yang disebutkan } \\
\text { dalam naskah } \\
\text { Sanghyang Siksa } \\
\text { Kanda ing } \\
\text { Karesian }\end{array}$ & $\begin{array}{l}\text { Perkakas ngahuma } \\
\text { sama dipergunakan } \\
\text { untuk nyawah } \\
\text { (bersawah), dan untuk } \\
\text { ngebon (berkebun) }\end{array}$ \\
\hline $\begin{array}{l}\text { Kujang untuk } \\
\text { narawas atau } \\
\text { kujang pamangkas } \\
\text { untuk ngabukbak }\end{array}$ & $\begin{array}{l}\text { Kored adalah perkakas } \\
\text { serba guna untuk } \\
\text { membersihkan lahan } \\
\text { huma }\end{array}$ \\
\hline $\begin{array}{l}\text { Baliung, alat } \\
\text { multifungsi } \\
\text { sebagai rimbas } \\
\text { (cangkul) dan } \\
\text { kampak, untuk } \\
\text { ngabaladah }\end{array}$ & $\begin{array}{l}\text { Arit untuk memotong } \\
\text { rumput, ranting dan } \\
\text { semak. Juga } \\
\text { dipergunakan untuk } \\
\text { memotong jerami } \\
\text { padi. }\end{array}$ \\
\hline $\begin{array}{l}\text { Patik (kapak } \\
\text { besar) untuk } \\
\text { menebang pohon } \\
\text { dan ranting }\end{array}$ & $\begin{array}{l}\text { Bedog, dan } \\
\text { congkrang, peralatan } \\
\text { serbaguna untuk di } \\
\text { pedalaman hutan. }\end{array}$ \\
\hline $\begin{array}{l}\text { Kored untuk } \\
\text { nyacar, nukuh dan }\end{array}$ & $\begin{array}{l}\text { Dekol sejenis kapak } \\
\text { genggam untuk }\end{array}$ \\
\hline
\end{tabular}




\begin{tabular}{ll} 
ngoyos & memotong ranting \\
\hline $\begin{array}{l}\text { Sadap atau peso } \\
\text { sadap untuk }\end{array}$ & $\begin{array}{l}\text { Gacok, gaet, pacul } \\
\text { adalah perkakas }\end{array}$ \\
memotong padi, & nyawah untuk \\
untuk menyadap & mempersiapkan lahan \\
kawung (pohon & $\begin{array}{l}\text { huma } \text { sehingga lebih } \\
\text { enau) }\end{array}$ \\
\hline
\end{tabular}

Perkakas huma yang dipergunakan di kawasan padukuhan, masih mengikuti patikrama tatanen, yang tidak melakukan proses perubahan kondisi lahan secara drastis. Tanah yang digarap dilakukan seperlunya sekedar untuk mendapatkan oksigen dan hara tanah yang menumbuhkan tanaman padi. Perkakas manual ini merupakan perkakas serbaguna, yang penggunaannya sangat meluas dan cenderung multifungsi.

Perkakas kerja yang dipergunakan dalam proses ngahuma di desa, cenderung mempergunakan berbagai perkakas yang umum dipergunakan dalam pertanian konvensional masa kini. Tidak mengenal kujang sebagai perangkat khusus dalam ngahuma. Terdapat perkakas serbaguna yang dipakai untuk pertanian sawah, kebun dan kehutanan.

\section{PENUTUP}

Bahwa Tatanen Huma Sunda di padukuhan dimaknai sebagai aturan baku dalam proses ngahuma sebagai landasan operasional kerja sesuai petunjuk atau pikukuh leluhur. Lokasi huma yang berada di hutan titipan dimaknai sebagai upaya melindungi ekosistem hutan dari eksplorasi dan eksploitasi.

Baik di kawasan padukuhan maupun pedesaan tidak dikenal adanya pembakaran hutan ataupun penebangan pohon besar untuk huma. Aktivitas yang mendapatkan izin adalah pembakaran semak belukar dan rumput. Baik pahuma di padukuhan maupun pedesaan, keduanya sangat prihatin dengan adanya kasus pembakaran hutan di Indonesia.

Pahuma yang bekerja di kawasan kehutanan, merupakan benteng terdepan dalam menghadapi para perambah hutan, penebang liar dan pembakar hutan, yang dinilai sangat tidak memiliki prinsip yang respektif terhadap alam. Pahuma memiliki karakter yang kuat sebagai penjaga hutan, karena selain memahami lingkungan hutan sebagai eksosistim mutualistik, pahuma dapat mengurangi kemungkinan perusakan hutan oleh berbagai anasir yang merugikan bisnis kehutanan.

\section{Patikrama Tatanen Huma Sunda} pada dasarnya merupakan konsep pemeliharaan ekosistem yang dilandasi oleh spiritualitas dan nilai-nilai religius dalam menjaga alam semesta yang menjadi titipan Tuhan Yang Maha Esa. Jika manusia menghargai lingkungannya, maka alam sekitarnya akan menjaga manusia sebagai bagian dari alam yang memiliki keterkaitan emosional, baik secara fisik maupun psikis.

Patikrama yang meminta manusia memperlakukan padi dengan hormat, bukan berarti mempersonalisasikan padi sebagai perwujudan Dewi Sri Sanghyang Pohaci, namun lebih ditujukan pada perlunya memperhatikan lingkungan lebih baik. Pembagian hutan yang terdiri dari hutan larangan, hutan lindung dan hutan garapan, ditujukan untuk memahami lingkungan hutan untuk dijaga dengan sebaik-baiknya.

Keberadaan masyarakat padukuhan yang konservatif, memiliki fungsi yang sangat penting dan strategis untuk memahami konsep dan cara berfikir leluhur yang mampu mempertahankan ekosistem sedemikian kokohnya. Masyarakat padukuhan memiliki kearifan yang perlu dipelajari oleh masyarakat padesaan yang banyak berubah, yang dikhawatirkan berubah tanpa arah.

Perubahan huma di masyarakat pedesaan menjadi sawah, merupakan perubahan politik dalam dimensi sejarah yang menyebabkan masyarakat pahuma mengalihkan kemampuan ngahuma menjadi panyawah. Pengaruh pemerintahan Mataram dan VOC yang secara besar-besaran membuka sawah di kawasan pedesaan, atau padukuhan yang 
menjadi padesaan, merupakan kenyataan pahit yang merubah paradigma masyarakat Sunda terhadap pola bertanam padi yang menjadi komoditas komersial.

Pahuma di kawasan pedesaan bersifat fleksibel, yaitu kegiatan ngahuma sebagai kegiatan alternatif yang disesuaikan dengan situasi dan kondisi alam. Pada musim kemarau panjang dan masa paceklik, huma merupakan solusi alternatif yang sangat membantu petani mendapatkan pangan.

Pada masa kini, terutama saat musim kemarau panjang, banyak sawah ratusan hektar mengalami gagal panen karena padi kekeringan akibat tanah mengeras dan air mengering. Di saat seperti ini, banyak panyawah yang melihat dan mempertimbangkan tentang pentingnya huma. Jika huma tetap ada di kawasan yang biasa kering dan kurang suplai air, maka petani memiliki cadangan pangan.

Hasil padi huma lebih sedikit dari sawah, karena bersifat untuk konsumsi pribadi atau keluarga yang tidak diperjualbelikan. Padi huma belum bisa dikembangkan sebagai komoditi pertanian produktif. Jika dikembangkan secara luas, huma dapat dikembangkan tanpa perlu membuka hutan atau membutuhkan infrastruktur yang berbiaya tinggi. Dengan menanam padi di antara pepohonan yang tinggi, menjadikan padi lebih terpelihara karena terlindungi kanopi pohon. Tidak diperlukan suplai air, karena diantara pohon, padi akan menerima nutrisi dari embun pagi dan hujan.

Keberadaan pahuma di kawasan hutan lindung ataupun hutan produktif yang dimiliki Dinas Perhutani, sangat bermanfaat sebagai patner kerja yang dapat memberikan sumbangsih menjaga hutan, melestarikan ekosistem dan mendukung produktivitas produk kehutanan (agroforestri).

Masyarakat pahuma di lingkungan padesaan, pada dasarnya memiliki kearifan lokal yang bersumber dari kemampuan leluhurnya dalam mengadaptasikan patikrama tatanen huma Sunda menjadi cara bekerja di huma pedesaan. Kearifan dari pahuma kasepuhan Sunda yang dilestarikan, merupakan bukti keterikatan dengan akar budaya Sunda yang melekat dan tak lekang dari perubahan zaman.

\section{UCAPAN TERIMA KASIH}

Ucapan terima kasih dihaturkan atas pendanaan Hibah Penelitian Terapan Unggulan Perguruan Tinggi (PTUPT) tahun 2018 dari DRPM Ditjen Penguatan Risbang, Kementerian Riset, Teknologi dan Pendidikan Tinggi Republik Indonesia.

\section{DAFTAR SUMBER}

\section{Jurnal, Makalah, Laporan Penelitian, Skripsi, dan Tesis}

Iskandar, J. 2004. "Mengkaji Kearifan Ekologi Komunitas Baduy Dalam Menghadapi Kekeringan" dalam Sosiohumaniora, Vol. 6 No. 2. Hlm.108 - 121.

Johan Iskandar, B. S. 2015. "Studi Etnobotani Keanekaragaman Tanaman Pangan pada 'Sistem Huma' dalam Menunjang Keamanan Pangan Orang Baduy". Pros Sem NasS Masy Biodiv Indon Vol. 1 Nomor 6. Hlm. 1265-1272.

Putra, E. S. 2010.

Kajian Bentuk dan Fungsi pada Kujang Huma Pamangkas. Thesis. ITB.

Putra, E. S. 2011. "Interpretasi Visual terhadap Bentuk dan Fungsi Kujang Huma Pamangkas dengan Uji ANOVA (Analysis Of Variance) dan VAS (Visual Analog Scale)" . dalam Itenas Rekarupa No.1 Vol.1 Januari - Maret 2011. Hlm. 28-34.

Rohmana, J. A. 2014. "Perempuan Dan Kearifan Lokal: Performativitas Perempuan Dalam Ritual Adat Sunda" dalam Musâwa, Vol. 13 No. 2. Hlm. 151-165.

Rusmana, T. 2018. "Rekontruksi Nilai-Nilai Konsep Tritangtu Sunda Sebagai Metode Penciptaan Teater Ke Dalam Bentuk Teater Kontemporer" dalam MUDRA Jurnal Seni Budaya Vol. 33 Nomor. 1. Hlm. 114 - 127. 
Satriadi, Y. P. 2015. "Huma Orang Baduy Dalam Pembentukan Sikap Swasembada Pangan". dalam Patanjala Vol. 7 No. 3. Hlm. 559 - 574.

Senoaji, G. 2012. "Pengelolaan Lahan Dengan Sistem Agroforestri Oleh Masyarakat Baduy Di Banten Selatan". dalam Bumi Lestari Vol. 12 No. 2. Hlm. 283-293.

Sumardjo, J. 2009. "Kosmologi dan Pola Tiga Sunda" dalam Imaji Vol. 4 No. 2. Hlm.101-110.

\section{Buku}

Danasasmita, Saleh, A. D. 1986.

Kehidupan masyarakat Kanekes. Bandung: Bagian Proyek Penelitian dan Pengkajian Kebudayaan Sunda (Sundanologi), Direktorat Jendral Kebudayaan, Departemen Pendidikan dan Kebudayaan.

Danasamita, S. 1987.

Sewaka Darma, Sanghyang Siksa Kanda ing Karesian, Amanat Galunggung. Bandung: Proyek Penelitian dan Pengkajian Budaya Sunda. Direktorat Jenderal Kebudayaan. Departemen Pendidikan dan Kebudayaan RI.

Gunawan, A. 2010.

Seri Sundalana 9: Perubahan Pandangan Aristokrat Sunda. Bandung: Pusat Studi Sunda.

Iskandar, J. d. 2011.

Agroekosistem Orang Sunda. Bandung: Kiblat Buku Utama.

Nurroh, S. 2014.

Studi Kasus: Kearifan Lokal (Local Wisdom) Masyarakat Suku Sunda Dalam Pengelolaan Lingkungan yang Berkelanjutan . Yogyakarta: Gajahmada University.

Putra, E. S. 2012.

Prosedur Ergonomi Dalam Patikrama Tatanen Huma Sunda. Seminar Nasional Ergonomi dan Kongres PEI 2012 (pp. G1-G8). Bandung: Universitas Widyatama Press ISBN:978-602-170850-7.

Spradley, J. P. 2007.

Metode Etnografi. Yogyakarta: Tiara Wacana.
Zoetmulder, P. J. 2006.

Kamus Jawa Kuno-Indonesia. Jakarta: Gramedia Pustaka Utama. 
